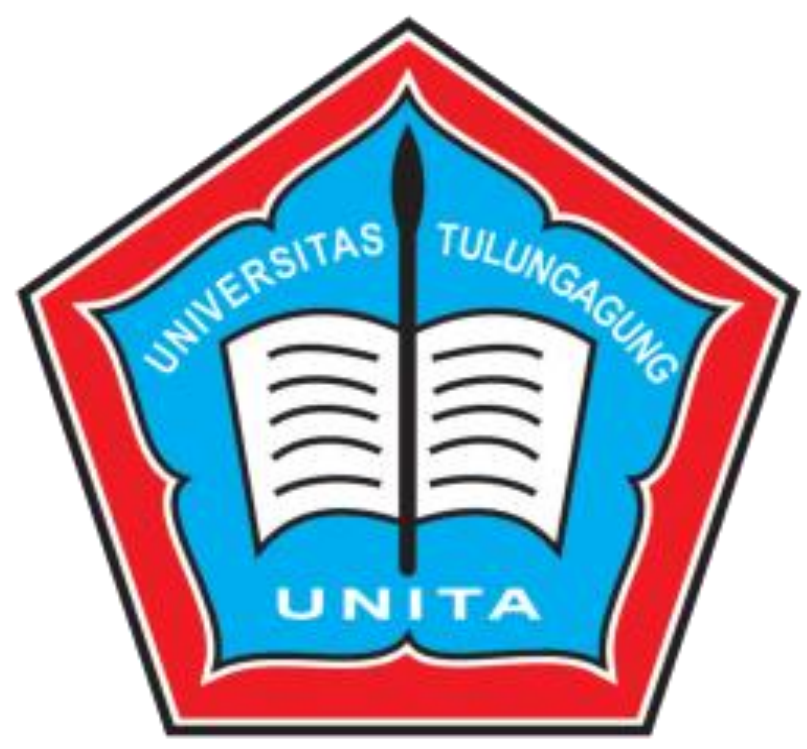

Disusun oleh:

1. ALFIAN BAHARDIANSYAH (1960301100045)

2. RIKI YULIANTO (1960301100028)

3. WINDA TRIANTIKA (1960301100065)

4. NURLITA NOVITASARI (2060301200054)

UNIVERSITAS TULUNGAGUNG

FAKULTAS EKONOMI

AKUNTANSI

2019/2020 


\title{
“ANALISIS PERHITUNGAN PAJAK PERTAMBAHAN NILAI (PPN) PADA PERUSAHAAN AULIA CLUB "HERBALLIFE"
}

\begin{abstract}
This study aims to determine the calculation of the Value Added Tax (VAT) which is in use at the company. VAT is a tax to calculate how much the value contained in a product. From the data obtained from the company, the authors conducted an analysis on the calculation of the Value Added Tax (VAT) applies if the company is in accordance with the provisions of the new tax law. research method is the primary data analysis technique of data through interviews. The results that the company was not in accordance with the Act changes the new tax, so the income earned less because the tax rate is toolarge.
\end{abstract}

Keywords: PPN, tax rates, tax laws.

\begin{abstract}
Abstrak: Penelitian ini bertujuan untuk mengetahui perhitungan Pajak Pertambahan Nilai (PPN) yang di pakai pada perusahaan. PPN adalah pajak untuk menghitung berapa besar pertambahan nilai yang terkandung dalam suatu barang. Dari data yang diperoleh dari perusahaan, penulis melakukan analisis pada perhitungan Pajak Pertambahan Nilai (PPN) yang dipakai perusahaan apakah sudah sesuai dengan Undang-Undang Perpajakan yang baru. metode penelitian adalah data primer dengan teknik analisis data melalui interview. Hasil penelitian bahwa oleh perusahaan masih belum sesuai dengan perubahan Undang-Undang Perpajakan yang baru, sehingga laba yang diperoleh lebih sedikit karena tarif pajak terlalu besar.
\end{abstract}

Kata kunci: PPN, Tarif pajak, Undang-undang perpajakan. 


\section{Pendahuluan}

\section{Latar belakang}

PT Herbalife Indonesia adalah perusahaan produk nutrisi dan kesehatan kulit dunia.,Di Indonesia, Herbalife berpusat di Jakarta dan telah memiliki puluhan outlet di Indonesia, dan salah satu otletnya adalah Perusahaan Aulia yang penjualannya berupa penjualan sendiri maupun sistem reseller. Karena memperoleh keuntungan dari penjualan tersebut, maka perusahaan Aulia di kenakan biaya pajak. Perusahaan Aulia dalam perhitungan pajak pertambahan nilainya dengan cara dari mendapatkan penjualan dikalikan dengan tarif pajak pertambahan nilai jadi, jumlah tersebut adalah yang mejadi pajak pertambahan nilai perusahaan itu.

Dengan dikeluarkannya pajak akan dapat membantu meringankan biaya pembangunan dan dapat mensejahterakan rakyat Indonesia. Dengan adanya pajak tersebut maka kami dapat simpulkan bahwa pajak tidak hanya pada penjualan produk saja tetapi jasa juga dikenakan biaya pajak selain itu, semua yang menghasilkan keuntungan akan dikenakan pajak. Penerimaan pajak merupakan salah satu sumber pembiayaan pembangunan nasional yang cukup dominan. Perubahan struktur ekonomi dari ekonomi agraris ke ekonomi industri mengakibatkan semakin meningkatnya peran pajak, khususnya Pajak Pertambahan Nilai (PPN), terhadap pembiayaan pembangunan nasional. Menyadari akan hal ini, penggalian dan usaha peningkatan penerimaan pajak terus diupayakan.

Menurut (Prabowo, 209AD) Pungutan pajak mengurangi pengahsilan atau kekayaan indiviu tetapi sebaliknya merupakan penghasilan masyarakat yang kemudian dikembalikan ke masyarakat, melalui pengeluaran pengeluaran rutin dan pengeluaran pengeluaran pembangunan yang akhirnya kembali kemasyarakat yang bermanfaat bagi rakyat, bagi yang membayar maupun tidak. Pajak memiliki peran penting bagi kehidupan bernegara, khususnya dalam pembangunan, karena pajak merupakan sumber penghsilan Negara untuk membiayai semua pengeluaran, termasuk untuk pengeluaran pembangunan.

System pajak pertambahan nilai (PPN) di Indonesia adalah self assessment system, yang berarti wajib diberikan kepercayaan untuk menghitungkan, menyetorkan, dan melaporkan sendiri atas pajak yang terhutang terhadap Negara merupakan cara yang paling mudah yang dilakukan.

Pemerintah untuk memungut pajak, yaitu dengan cara mewajibkan wajib pajak untuk melakukan pungutan dan pemungutan pajkanya oleh pihak lain. Dengan biaya 
yang besar untuk memungut pajak, dalam pemungutan pajak subjek dan objek harus jelas. Oleh karena itu harus dikelola dengan baik dan benar sehingga data wajib pajak sesuai, selain itu traif pajak harus ditentukan berdasarkan ketentuan yang berlaku saat itu. Dengan demikian wajib pajak alan rutin dan patuh membayar pajak. Subjek pajak adalah orang, badan atau kesatuan yang lainya yang telah memenuhi syarat subyektif. Yaitu bertempat tinggal atau berkedudukan di Indonesia . objek pajak adalah apa yang kenakan pajak karena menyangkut apa yang dikenakan ata tidak dikenakanya pajak atas objek dimaksud. Sehingga dalam UU perpajakn kita selalu dengan tegas dinyatakan apa yang dimaksud objek setiap jenis pajak.

\section{Rumusan Masalah}

Bagaimana perhitungan Pajak Pertambahan Nilai (PPN) pada PT.Aulia "Herballife" apakah sudah sesuai dengan undang-undang pajak pertambahan yang berlaku.

\section{Tujuan Penelitian}

Tujuan penelitian ini adalah Peneliti ingin mengetahui bagaimana cara perusahaan dalam menghitung Pajak Pertambahan Nilai (PPN), apakah sesuai dengan undangundang yang berlaku.

\section{Landasan Teori}

\section{Pengertian Pajak}

Menurut Mardiasmo, (2003:10) Pajak adalah iuran wajib, berupa uang atau barang, yang dipungut oleh penguasa berdasarkan norma-norma hukum, guna menutup biaya produksi barang-barang dan jasa-jasa dalam mencapai kesejahteraan umum.

Penerimaan dari sektor pajak merupakan sumber penerimaan negara terbesar. Banyak cara yang dilakukan Direktorat Jenderal Pajak untuk meningkatkan penerimaan negara dari sektor pajak (Mardiasmo, 2009).

Menurut (Waluyo. Ilyas, 2002) Pajak adalah iuran kepada Negara (yang dapat dipaksakan) yang terutang oleh yang wajib membayarnya menurut peraturanperaturan, dengan tidak mendapat prestasi kembali yang langsung dapat ditunjuk, dan 
yang gunanya adalah untuk membiayai pengeluaran-pengeluaran umum berhubungan dengan tugas Negara yang menyelenggarakan pemerintah.

Menurut (Helmy, 2005b)“Pajak adalah prestasi pemerintah yang terutang melalui norma-norma umum dan yang dapat dipaksakan, tanpa adanya kontra prestasi yang dapat ditunjukkan dalam hal yang individual, maksudnya adalah membiayaipengeluaran pemerintah".

Menurut(Hidayah, 2008), "Pajak adalah iuran yang harus dibayar oleh wajib pajak (masyarakat) kepada Negara (pemerintah) berdasarkan undang-undang dan tidak memperoleh balas jasa secara langsung.

\section{Ciri-ciri Pajak}

a. Pajak peralihan kekayaan dari orang atau badan kepemerintah.

b. Pajak dipungut dengan kekuatan Undang-undang serta aturan pelaksanaannya, sehingga dapat dipaksakan.

c. Pajak digunakan untuk kepentinganumum.

d. Dalam pembayaran pajak tidak dapat ditunjukkan adanya kontreprestasi langsung secara individual kepadapemerintah.

e. Pajak dipungut oleh Negara baik oleh pemerintah pusat maupun pemerintah daerah.

f. Pajak diperuntukkan bagi pengeluaran-pengeluaran pemerintah, yang bila dari pemasukkannya masih terdapat surplus, maka dipergunakan untuk membiayai investasi publik.

\section{Fungsi Pajak}

a. Fungsi budgetair, yaitu pajak-pajak disini merupakan suatu alat atau sumber untuk memasukkan uang sebanyak-banyaknya ke kas Negara yang pada waktunya akan digunakan untuk membiayai pengeluaran-pengeluaran rutin apabila setelah itu ada sisa, maka surplus ini dapat digunakan untuk membiayai investasi pemerintah.

b. Fungsi mengatur, yaitu bahwa pajak-pajak dalam hal ini digunakan sebagai alat untuk mencapai tujuan-tujuan tertentu yang letaknya di luar bidang keuangan.

\section{Pengertian Pajak Pertambahan Nilai}

Pajak Pertambahan Nilai (PPN) adalah pajak yang dapat dikenakan terhadap 
penyerahan atau impor barang kena pajak atau jasa kena pajak yang dilakukan oleh pengusaha kena pajak dan dapat dikenakan berkali-kali setiap ada Pajak Pertambahan Nilai (PPN) dan dikreditkan (Suandy, 2003)

Pajak Pertambahan Nilai (PPN) yaitu : "pertambahan nilai adalah harga beli atau biaya sewa yang harus dikeluarkan untuk mengelola lebih lanjut barang yang dibeli menjadi barang yang siap untuk jual" (Urifa, 2009)

Dengan demikian pertambahan nilai itu sendiri timbul karena digunakannya faktorfaktor produksi pada setiap jalur perusahaan dalam menghasilkan, menyalurkan dan memperdagangkan barang atau dalam memberikan pelayanan jasa. Semua biaya yang berkaitan dengan menghasilkan, menyalurkan dan memperdagangkan atau dalam memberikan pelayanan jasa merupakan unsur pertambahan nilai yang menjadi dasar pengenaan Pajak Pertambahan Nila(PPN). Jadi dapat disimpulkan bahwa Pajak Pertambahan Nilai (PPN) adalah pajak yang dikenakan atas pertambahan nilai dari barang kena pajak atau jasa kenapajak.

Dalam Peraturan Perpajakan No. 18 Tahun 2000 mengenai Pajak Pertambahan Nilai banyak istilah atau pengertian-pengertian penting yang perlu diketahui dalam Pajak Pertambahan Nilai (PPN) antara lain :

- Pengusaha adalah orang pribadi atau badan dalam bentuk apa pun yang dalam lingkungan perusahaan atau pekerjaannya menghasilkan barang, mengimpor barang, mengekspor barang, melakukan usaha dagang, memanfaatkan barang tidak berwujud dari luar pabean, melakukan usaha jasa dari luar daerah pabean.

- Pengusaha Kena Pajak (PKP) adalah orang atau badan dalam bentuk apapun yang dalam lingkungan pekerjaannya atau perusahaannya menghasilkan barang, mengimpor barang, mengekspor barang, melakukan usaha perdagangan atau melakukan usaha jasa yang dikenakan Pajak Pertambahan Nilai.

- Badan adalah sekumpulan orang atau modal yang merupakan kesatuan baik yang melakukan usaha maupun yang tidak melakukan usaha yang meliputi perseroan terbatas, perseroan komanditer, perseroan lainnya, badan usaha milik Negara atau daerah dengan nama dan dalam bentuk apa pun, firma kongsi, koperasi, dana pensiun, persekutuan, perkumpulan, yayasan, organisasi 
massa, organisasi social politik, atau organisasi yang sejenis, lembaga, bentuk usaha tetap, dan bentuk badanlainnya.

- Barang Kena Pajak (BKP) adalah barang berwujud yang menurut sifat atau hukuman dapat berupa barang bergerak maupun barang tidak bergerak sebagai hasil proses pengolahan (pabrikasi) yang dikenakan pajak berdasarkan undang-undang.

- Jasa adalah setiap kegiatan pelayanan berdasarkan suatu perikatan atau perbuatan hukum yang menyebabkan suatu barang atau fasilitas atau kemudahan atau hak tersedia untuk dipakai termasuk jasa yang dilakukan untuk menghasilkan barang karena pesanan atau permintaan dengan bahan dan atas petunjuk daripemesan.

- Jasa Kena Pajak (JKP) adalah semua kegiatan usaha dan pemberian pelayanan berdasarkan suatu peringkatan atau perbuatan hukum yang menyebabkan suatu barang, fasilitas atau hak tersedia untuk dipakai, yang dikenakan Pajak PertambahanNilai.

- Penyerahan Jasa Kena Pajak adalah setiap kegiatan pemberian Jasa Kena Pajak sebagaimana dimaksud pada huruf d, termasuk Jasa Kena Pajak yang digunakan untuk kepentingan sendiri atau Jasa kena Pajak yang diberikan secara cuma-cuma oleh Pengusaha KenaPajak.

- Daerah pabean adalah wilayah negara RI yang didalamnya berlaku peraturan perundangundangan Pabean.

- Masa Pajak adalah jangka waktu yang lamanya sama dengan satu bulan takwin kecuali ditetapkan lain oleh MenteriKeuangan.

- Tahun Pajak adalah jangka waktu 1 (satu) tahun takwim kecuali bila Wajib Pajak menggunakan tahun buku yang tidak sama dengan tahun takwim. Jika Wajib Pajak menggunakan tahun buku tidak sama dengan tahun takwim maka tahun pajak adalah tahun dimana lebih dari enam bulan ada didalamnya.

- Bagian Tahun Pajak adalah bagian dari jangka waktu 1 (satu) tahunpajak.

- Pajak yang Terutang adalah pajak yang harus dibayar pada suatu saat, dalam Masa Pajak, dalam Tahun Pajak ada dalam Bagian Tahun Pajak menurut ketentuan peraturan perundang-undanganperpajakan.

- Faktur Pajak adalah bukti pemungutan pajak yang dibuat oleh Pengusaha Kena Pajak (PKP) atau Direktoral Jendral Bea Cukai pada saat penyerahan Barang 
Kena Pajak (BKP) atau impor Barang Kena Pajak(BKP).

- Pajak Masukan adalah Pajak Pertambahan Nilai (PPN) yang dibayar oleh Pengusaha Kena Pajak (PKP) pada waktu pembelian Barang Kena Pajak (BKP) penerimaan Jasa Kena Pajak (JKP) atau impor Barang Kena Pajak (BKP).

- Pajak Keluaran adalah Pajak Pertambahan Nilai (PPN) yang dipungut oleh Pengusaha Kena Pajak (PKP) pada waktu penyerahan Barang Kena Pajak (BKP) atau Jasa Kena Pajak(JKP).

- Kredit Pajak untuk Pajak Pertambahan Nilai adalah pajak masukan yang dapat dikreditkan setelah dikurangi dengan pajak yang telah dikompensasikan, yang dikurangkan dari pajak yangterutang.

\section{Subyek Pajak PertambahanNilai}

Subyek pajak adalah mereka yang menjadi penanggung jawab atas hutang pajak yang bertanggung jawab atas penyetoran pajak ke kas Negara berdasarkan Undang- undang No. 18 Tahun 2000 adalah:

a. Pengusaha yang menurut Undang-undang harus dikukuhkan menjadi Pengusaha Kena Pajak (PKP) pengusaha atau wajib pajak yang otomatisadalah:

1. Pabrikan atau produsen termasuk pengusaha real estatel industrial estatel developer atau pengusaha yang menghasilkan barang kenapajak.

2. Pengusaha yang mengimpor barang kenapajak.

3. Pengusaha yang mempunyai hubungan istimewa dengan pabrikan atau importer.

4. Agen utama dan penyaluran utama dari pabrikan atauimporter.

5. Pemegang hak patent dan merk dagang dari barang kenapajak.

6. Pemborong/ kontraktor/ subkontraktor bangunan dan harta tetaplainnya

7. Pengusaha yang tidak termasuk ruang lingkup pengenaan pajak akan tetapi menyatakan memilih untuk dikukuhkan menjadi Pengusaha Kena Pajak (PKP) ialah:

1. Eksportir

2. Pedagang yang menjual Barang Kena Pajak(BKP). 


\section{Obyek Pajak Pertambahan Nilai}

Menurut (Helmy, 2005a) Obyek Pajak Pertambahan Nilai dikenakan sebagai berikut :

- Penyerahan Barang Kena Pajak di dalam daerah pabean yang dilakukan pengusaha.

- Penyerahan barang yang dikenekan pajak harus memenuhi syarat-syarat sebagai berikut :

1. Barang berwujud yang diserahkan merupakan Barang KenaPajak,

2. Barang tidak berwujud yang diserahkan merupakan Barang Kena Pajak tidak berwujud,

3. Penyerahan dilakukan di dalam daerah pabean,dan

4. Penyerahan dilakukan dalam rangka kegiatan usaha ataukegiatan.

- Impor Barang BenaPajak.

- Penyerahan Barang Kena Pajak di dalam daerah pabean yang dilakukan oleh Pengusaha Penyerahan Jasa yang terutang pajak harus memenuhi syarat-syarat sebagai berikut:

1. Jasa yang diserahkan merupakan Jasa KenaPajak,

2. Penyerahan dilakukan didalam daerah pabean, dan

3. Penyerahan dilakukan dalam kegiata usaha ataupekerjaannya.

a. Pemanfaatan Barang Kena Pajak tidak berwujud dari luar daerah pabean di dalam daerah pabean.

b. Pemanfaatan Jasa Kena Pajak dari luar daerah pabean di dalam daerahpabean.

c. Ekspor Barang Kena Pajak oleh Pengusaha KenaPajak.

d. Kegiatan membangun sendiri yang tidak dilakukan dalam kegiatan usaha atau pekerjaan oleh orang pribadi ataubadan.

e. Panyerahan aktiva oleh Pengusaha Kena Pajak yang menurut tujuan semula aktiva tersebut tidak untuk diperjual belikan, sepanjang Pajak Pertambahan Nilai yang dibayar pada saat perolehannya dapat dikreditkan.

Tarif Pajak Pertambahan Nilai menurut ketentuan Undang-undang RI Tahun 2000 pasal 7 adalah:

Tarif Pajak Pertambahan Nilai adalah10\%. 
Tarif Pajak Pertambahan Nilai atas ekspor barang kena pajak adalah 0\% (nol persen). Dengan peraturan pemerintah tarif pajak dapat diubah serendah-rendahnya 5\% (lima persen) dan setinggi-tingginya $15 \%$.

Pajak Pertambahan Nilai untuk pabrikan yaitu $10 \%$ untuk perhitungan pajak keluarannya.

\section{Perhitungan Pajak Pertambahan Nilai}

Besarnya Pajak Pertambahan Nilai (PPN) dapat dihitung dengan selisih antara pajak yang telah dipungut pada saat penjualan atau penyerahan suatu barang atau jasa kena pajak. Penerimaan jasa kena pajak atau import barang kena pajak (pajak masukan).Apabila dalam suatu masa pajak,pajak keluaran lebih besar dari pada pajak masukkan, maka selisihnya merupakan Pajak Pertambahan Nilai (PPN) yang harus dibayar oleh Pengusaha Kena Pajak. Apabila dalam suatu masa pajak, pajak masukkan yang dapat dikreditkan lebih besar dari pajak keluaran, maka selisihnya merupakan kelebihan pajak yang dapat dikompensasikan pada masa pajak berikutnya.

\section{Mekanisme Pengkreditan}

(Mardiasmo, 2011) Pembeli Barang Kena Pajak, penerima Jasa Kena Pajak, pengimpor Barang Kena Pajak, pihak yang memanfaatkan Jasa Kena Pajak Tidak Berwujud dari luar Daerah Pabean, atau pihak yang memanfaatkan Jasa Kena Pajak dari luar Daerah Pabean wajib membayar Pajak Pertambahan Nilai dan berhak menerima bukti pungutan pajak. Pajak Pertambahan Nilai yang seharusnya sudah dibayar tersebut merupakan Pajak Masukan bagi pembeli Barang Kena Pajak, penerima Jasa Kena Pajak, pengimpor Barang Kena Pajak, pihak yang memanfaatkan Barang Kena Pajak Tidak Berwujud dari luar Daerah Pabean, atau pihak yang memanfaatkan Jasa Kena Pajak dari luar Daerah Pabean yang bersetatus sebagai Pengusaha Kena Pajak.

\subsection{Faktur Pajak}

Faktur pajak adalah bukti pungutan pajak atau penyerahan jasa kena pajak,bukti pungutan pajak dibuat oleh pengusaha kena pajak yang melakukan penyerahan barang kena pajak atau penyerahan jasa kena pajak, bukti atau pungutan pajak karena impor barang kena pajak yang digunakan oleh Direktorat Jendral Bea Cukai. 


\section{Metode Penelitian}

\section{Pendekatan Penelitian}

Pada penelitian ini, peneliti melakukan perbandingan antara Perhitungan Pajak Pertambahan Nilai (PPN) yang diterapkan di dalam perusahaan terhadap kajian teoritis yang terdapat pada undang-undang Perpajakan Indonesia yang dikeluarkan oleh pemerintah. Studi perbandingan yang dimaksud adalah dalam bentuk analisis kuantitatif deskriptif.

\section{Jenis Penelitian}

Dalam penelitian ini, jenis penelitian yang digunakan adalah penelitian deskriptif kuantitatif yaitu suatu penelitian yang menggunakan data kuantitatif yang terdapat dalam laporan keuangan dimana melalui teknik pengumpulan, pengolahan, penyederhanaan, penyajian dan analisis data, dan memberikan gambaran yang teratur tentang suatu peristiwa melalui observasi (Supardi, 2005).

\section{Subyek Penelitian}

Subyek penelitian ini adalah Perusahaan Aulia Club "Herbalife", sedangkan yang menjadi obyek pada penelitian ini yaitu data mengenai perhitungan Pajak Pertambahan Nilai (PPN) dan laporan laba rugi perusahaan.

\section{Jenis dan Sumber Data}

\section{Jenis data}

Data primer, yaitu sumber data penelitian yang diperoleh langsung oleh peneliti (tidak melalui media perantara), data primer berupawawancara.

Data sekunder, yaitu data yang diperoleh dalam bentuk yang sudah terjadi publikasi seperti, sejarah perusahaan, struktur organisasi, deskriptif jabatan, data-data perhitungan Pajak Pertambahan Nilai dan laporan laba rugi serta komponen yang ada pada perusahaan.

\section{Sumber data}

Data internal merupakan data penelitian yang berupa dokumen-dokumen akuntansi dan akuntansi yang dikumpulkan, dicatat dan disimpan didalam suatu organisasi. Dalam penelitian ini data intern dapat diperoleh dari perusahaan berupa laporan laba rugi, laporan perhitungan Pajak Pertambahan Nilai (PPN) dan data-data yang diperlukan. 


\section{Definisi operasional variabel}

Pajak Pertambahan Nilai (PPN) adalah pajak yang dapat dikenakan terhadap penyerahan atau impor barang kena pajak atau jasa kena pajak yang dilakukan oleh pengusaha kena pajak dan dapat dikenakan berkali-kali setiap ada Pajak Pertambahan Nilai (PPN) dan dikreditkan. (Suandy, 2003)

\section{Metode Analisis Data}

1. Melaksanakan perhitungan Pajak Pertambahan Nilai (PPN) menurut perusahaan dengan dibandingkan dengan perhitungan Pajak Pertambahan Nilai (PPN) menurut Undang-Undang Perpajakan tentang Pajak Pertambahan Nilai(PPN).

2. Menganalisis dan menarik kesimpulan atas perhitungan perbandingan Pajak Pertambahan Nilai (PPN) menurut perusahaan dengan perhitungan Pajak Pertambahan Nilai (PPN) menurut Undang-UndangPerpajakan.

3. Menganalisis perhitungan laporan laba rugi perusahaan setelah diketahui perhitungan perbandingan Pajak Pertambahan Nilai (PPN) menurut perusahaan dengan perhitungan Pajak Pertambahan Nilai (PPN) menurut Undang-Undang Perpajakan.

\section{Pembahasan}

Hasil Penelitian dan Pembahasan

Gambaran umum produk "Herbalife"

PT Herbalife Indonesia adalah perusahaan produk nutrisi dan kesehatan kulit dunia. Perusahaan ini didirikan tahun $\underline{1980}$ dan memperkerjakan sekitar 4,000 orang

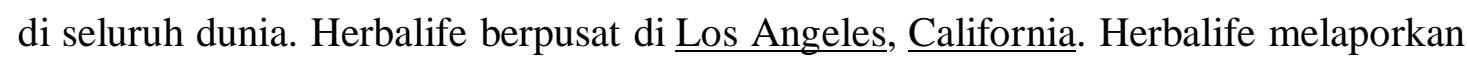
penjualannya dari 2.7 miliar USD dari 2.1 juta distibutor independen, dari seseorang yang melakukan pendapatan laba pada penjualan produk dan komisi tambahan dari struktur kompesasi pemasaran berjenjang. Perusahaan ini didirikan oleh Mark Hughes.

Di Indonesia, Herbalife berpusat di Jakarta dan telah memiliki puluhan outlet di Indonesia dan salah satu otletnya adalah Perusahaan Aulia yang penjualannya berupa penjualan sendiri maupun sistem reseller.

Produk Herbalife telah mendapatkan sertifikat HALAL dari MUI No. 00140035740705. Selain itu juga telah mendapatkan sertifikat POM dan Depkes pada tiap kemasan produknya. 
Semua produk Herbalife telah lulus tes untuk:

- Megadose Law, yaitu larangan overdosis : Produk Herbalife tidak menyebabkan Overdosis.

- Labelling Law, yaitu larangan penggunaan : Produk Herbalife aman untuk semua orang.

Produk Herbalife bukan obat, bukan jamu dan bukan susu. Produk Herbalife merupakan nutrisi atau food suplement yang merupakan makanan tambahan yang membantu memenuhi kebutuhan gizi sehari-hari Anda dan keluarga. Kandungan gizi nutrisi Herbalife sama dengan makanan kita sehari-hari, yang menjadi perbedaan adalah tinggi protein, bukan karbohidrat serta mengandung 4 vitamin dan mineral dan mikronutrien penting yang tidak kita dapatkan dalam makanan kita sehari-hari.

Nutrisi Herbalife bekerja dengan konsep Nutri Seluler, yaitu memberikan nutrisi atau makanan dengan gizi seimbang untuk sel tubuh. Sel merupakan bagian terkecil dari manusia yang menyusun jaringan, organ dan membentuk satuan tubuh manusia. Dengan Nutrisi Herbalife, sel akan memperoleh zat yang dibutuhkan untuk berkembang dan untuk menggantikan sel-sel tubuh yang telah rusak. Karena sel-sel tubuh yang rusak ini lah yang menyebabkan kinerja tubuh tidak optimal, misal menjadi sakit, dsb. Dengan memiliki sel-sel tubuh yang prima, maka kesehatan dan fungsi tubuh pun akan bekerja lebih optimal dan kita menjadi tidak sakit-sakitan lagi atau yang sakit menjadi sembuh. Konsep dari nutrisi seluler adalah : CLEANSE - ABSORP - REGENERATION : - CLEANS : membersihkan vili - vili usus.

- ABSORP : dengan vili yang bersih, maka tubuh akan menyerap lebih banyak nutrisi yang masuk.

- REGENERATION : dengan banyaknya nutrisi yang masuk ke tubuh, maka sel-sel tubuh secara alami akan melakukan regenerasi atau pertumbuhan sel baru. Dengan sel-sel tubuh yang baru inilah kinerja tubuh optimal dan tubuh akan menjadi sehat.

Program Herbalife telah di uji secara klinis dengan teliti di Amerika dan Inggris. Semua penelitian-penelitian tersebut menunjukkan bahwa produk Herbalife aman di pakai untuk jangka waktu pendek ataupun jangka waktu lama. Setiap kemasan dari produk Herbalife harus lolos uji kualitas sebelum dikirimkan ke seluruh pelosok dunia.

Visi- Misi Perusahaan

VISI

Mengubah Kehidupan Orang Lain.

MISI 
Mengubah Kehidupan Orang Lain Dengan Menyediakan Peluang Bisnes Terbaik Dalam Penjualan Langsung Dan Produk Nutrisi Dan Pengurusan Berat Badan Yang Terulung Di Dunia.

\section{ETIKA KAMI}

Kami Melaksanakan Urusan Kami Secara Benar, Jujur Dan Beretika.

Kami Mengambil Jalan Terbaik.

\section{Pembahasan}

Dari hasil wawancara dan dokumentansi peneliti kepada ownwe dari PT Aulia, dapat disimpulkan bahwa perusahaan ini melakukan penerapan pajak pertambahan nilai dengan pembuatan faktur pajak, penyimpanan, pelaporan spt masa pajak pertambahan nilai, pemungutan sesuai dengan peraturan perundang-undang.

\section{Penerapan PajakPertambahan}

Dalam pelaksanaan penerapan pajak pertambahan nilai PT. Anugerah Mega Lestari melaksanakan hak dan kewajiban sesuai dengan Undang-Undang Pajak Pertambahan Nilai No. 42 Tahun 2009 yaitu :

a. . Membuat faktur pajak untuk setiap penyerahanBKP

b. Memungut pajak pertambahan nilai sebesar $10 \%$ dari nilai dasar pengenaan pajak dan transaksi atas penyerahan barang kenapajak.

c. Menyetorkan pajak terutang ke kas negara selambat-lambatnya akhir bulan berikutnya setelah berakhirnya masapajak.

d. Menyampaikan laporan perhitungan pajak pertambahan nilai dengan surat pemberitahuan masa dalam jangka 20 hari setelah akhir masapajak.

e. Membuat pencatatan pajak masukan dan pajakkeluaran.

f. Menyimpan faktur pajak dengan rapi danteratur

Analisis Penerapan Pajak Pertambahan Nilai

\section{Analisis Pembuatan FakturPajak}

dan lembar kedua untuk di arsipkan ke PT. Aulia club sebagai penyerah barang kenapajak. Menurut hasil wawancara dan dokumentasi yang telah peneliti lakukan, bahwa pembuatan faktur pajak yang dilakukan PT Aulia club telah sesuai dengan peraturan Undang-Undang Perpajakan No. 42 Tahun 2009. PT Aulia club telah menggunakan faktur pajak standart dari Dirjen Jendral Pajak. Faktur pajak dibuat 
perusahaan sebanyak dua rangkap, dimana lembar pertama untuk diserahkan kepada penerima barang kena pajak

\section{Analisis Pemungutan Pajak PertambahanNilai}

Dari pemungutan pajak pertambahan nilai PT. Aulia club peneliti melihat bahwa setiap pembelian dan penjualan dipungut sebesar $10 \%$ dari dasar pengenaan pajak untuk semua jenis barang kena pajak dan itu bearti telah melakukan pemungutan pajak pertambahan nilai sesuai dengan Undang-Undang Perpajakan no. 42 Tahun 2009.

\section{Analisis Penyetoran Pajak PertambahanNilai}

Dalam hasil wawancara terhadap informan kunci mbak mila bahwa penyetoran yang dilakukan PT. Aulia ternyata selalu tepat waktu dan tidak pernah terlambat yang dikarenakan setiap tahun 2019 bulan Januari sampai dengan Desember terdapat lebih bayar, menurut informan kunci yaitu bu mila bagian administrasi perpajakan terjadinya lebih bayar pada perusahaan ini dikarenakan pengusahan kena pajak atau PKP melakukan penyerahan barang kena pajak kepada pemungut PPN sehingga pajak PPN yang seharusnya dipungut oleh PKP tetapi dipungut oleh pemungut PPN dan penulis menemukan adanya beberapa faktur pajak yang belum dilaporkan perusahaan pada bulan Februari sehingga terjadinya lebih bayar PPN pada perusahaan tersebut.

\section{Analisis Penyampaian Pelaporan SPT Masa Pajak \\ Pertambahan Nilai}

Dalam penyampaian pelaporan SPT masa pajak pertambahan nilai PT. Aulia club telah melakukan pelaporan surat pemberitahuan masa pajak pertambahan nilai yang sesuai dengan sistem perpajakan di Indonesia yaitu menggunakan Self Assesment dimana perhitungan, penyetoran dan pelaporan dilakukan sendiri oleh wajib pajak pengusaha. PT. Aulia club melakukan pelaporan pajak pertambahan nilai dengan menggunakan surat pemberitahuan masa pajak 1111 yang terdiri dari pengkreditan pajak masukan atas pajak keluaran dan lebih bayar atau kurang bayar.

\section{Analisis Pencatatan Pajak PertambahanNilai}

Dalam melakukan pencatatan PT. Aulia club melakukan pencatatan pajak keluaran dan masukan, berikut contoh pencatatan pajak masukan PT. Aulia club : 
g. Pencatatan PajakKeluaran

PT. Aulia club melakukan penjualan sebesar Rp. 48.000.000, makapenghitungan sbb:

pajak pertambahan nilai Rp.3.200.000

pajak penghasilan $\quad$ Rp. $20000+$

jumlah pajak Rp. $3.22000_{-}$

$\begin{array}{ll}\text { Laba bersih setelah pajak } & \text { Rp.21.480.000 }\end{array}$

Pajak keluaran yang dapat dihitung adalah sebagai berikut :

Pendapatan

$10 \% \times$ Rp. $48.000 .000=$

Rp. 4.800 .000

\section{Total pajak keluaran}

Rp. 4800.000

Pembelian bahan baku

Rp. 5000.000

Total Pembelian bahan baku

Rp. $\mathbf{5 0 0 0 . 0 0 0}$

Pajak masukan yang dapat dikreditkan adalah :

$10 \%$ x Rp.5000.000

Rp. 500.000

Sehingga pajak pertambahan nilai sebagai berikut :

Pajak keluaran

Rp. 4800.000

Pajak masukan

Rp. $500.000-$

PPN yang terutang

Rp. 4.300.000

Dari data transaksi penjualan pada Perusahaan Aulia “ Herballife bulan Januari s/d Desember 2020 adalah sebagai berikut :

- Pendapatan dari penjualan produk Herballife sebesar Rp. 48.000.000

Pajak pertambahan nilai $10 \%$ x Rp. $48.000 .000=$ Rp. 4.800 .000 maka pajak

pertambahan nilai yang harus dibayar ke kas negara pada periode bulan desember 2020 adalah sebesar Rp. 4.800 .000 
Tabel

Laporan Laba Rugi Perusaan Aulia"Herballife

Periode 1 Januari s.d. 31 Desember 2020

\section{Pendapatan}

usaha :

I. PENDAPATANBERSIH
1. Penjualan
Rp. 48.000 .000
2. Returpenjualan
Rp.0

Dikurangi :

II. BIAYA USAHA

1. Biaya Pembelian Rp. 5.000 .000

2. Biaya Penjualan Rp. 450.000

3. Biaya Overhead:

Jumlah Biaya Usaha

Rp. 5.450.000-

Laba usaha

Rp. 42.550 .000

III. BIAYA OPERASIONAL

1. Gaji Karyawan

Rp. 12.000 .000

2. Alat Tulis Kantor, Fotocopy

Rp. 500.000

3. Biaya Transportasi

Rp. 1.400 .000

4. Biaya Telepon/Fax/Post

Rp. $\quad 500.000$

5. Biaya Listrik \& Air

Rp. 3.000 .000

6. Biaya lain-lain

Rp. $1.000 .000+$

Total Biaya Operasional

Rp. $18.400 .000_{-}$

LabaOperasional

Rp.24.150.000

\section{BIAYA LAIN-LAIN}

IV. Laba Sebelum pajak

Pajak penghasilan

Rp. 5.400 .000 
Rp. $1800.0000+$

Jumlah pajak

Rp. 7.200.000-

\section{Laba bersih setelah pajak}

\section{$\underline{\text { Rp. 16.950.0000 }}$}

Sumber : data Perusahaan Aulia "Herballife"

\section{Kesimpulan}

Dalam menghitung Pajak Pertambahan Nilai (PPN) dapat digunakan metode tidak langsung yaitu pajak keluaran dikurangi pajak masukan hasil yang diperoleh adalah merupakan pajak yang harus disetor ke kas Negara. Dalam mencatat Pajak Pertambahan Nilai untuk keperluan pembuatan laporan keuangan dibutuhkan informasi yang jelas tentang transaksi-transaksi yang berkaitan dengan Pajak Pertambahan Nilai yaitu transaksi penjualan dan pembeliannya.

Dari hasil analisis pada tahun 2020 laporan laba rugi diperoleh Pajak Pertambahan Nilai sejumlah Rp. 16.950 .000 (sudah termasuk pajak penghasilan). Dengan adanya perhitungan terhadap Pajak Pertambahan Nilai (PPN) pada PT. Aulia maka dapat diketahui besarnya pajak pertambahan nilai yang seharusnya menjadi beban perusahaan ini. 


\section{DAFTAR PUSTAKA}

Helmy, A. (2005a) diktat Perpajakan.

Helmy, A. (2005b) Hukum Perpajakan.

Hidayah, N. (2008) Ilmu Pengetahuan Sosial. Lamongan: UD Rismah Cendekia.

Mardiasmo (2003) Perpajakan. Yogyakarta: Andi offset.

Mardiasmo (2009) 'Perpajakan Indonesia', Edisi Revisi.Jogjakarta: Andi.

Mardiasmo (2011) 'Surat Pemberitahuan', Diseases of Aquatic Organisms.

Prabowo, R. G. M. (209AD) 'MEKANISME PEMUNGUTAN PPN dan PPnBM', p.

5.

Suandy, E. (2003) Hukum Pajak. Jakarta: Salemba Empat.

Suharsimi (2002a) Prosedur Penelitian. Jakarta: T Rineka Cipta.

Suharsimi (2002b) Prosedur Penelitian. Jakarta: T Rineka Cipta.

Supardi (2005) Metode Penelitian Ekonomi dan Bisnis. Yogyakarta: IKAPI.

Urifa, A. (2009) Evaluasi Atas Perhitungan Pajak Pertambahan nilai Pada Perusahaan Rokok Roky Internasional Kalen Kedungpring Lamongan. Lamongan.

Waluyo. Ilyas, W. (2002) Perpajakan Indonesia. jakarta: Salemba Empat. 